\title{
THEME ADDRESS-FIRE HIGHLIGHTS IN THE DEVELOPMENT OF FOREST FIRE PROTECTION IN CANADA ${ }^{1}$
}

\author{
By H. W. BEALL 2
}

He graduated from the University of Toronto with the degree of B.Sc.F. in 1932 and has been employed since that time with the Federal Forestry Branch. From graduation until 1940 he was engaged on forest fire research projects, particularly in studies of fire danger measurement which included field work in Ontario, Quebec, New Brunswick and Alberta. Following four years' service with the R.C.A.F. during the war, he was until 1950 in charge of the Forest Fire Protection Section of the Forestry Branch. Since that time he has been Chief of the Forestry Operations Division, the main duties of which are concerned with administering the Federal-Provincial forestry agreements under the Canada Forestry Act.

\section{INTRODUCTION}

In selecting Forest Protection as the topic for discussion at this Annual Meeting of the Canadian Institute of Forestry, the committee responsible has, I believe, chosen a particularly appropriate and timely subject. It is appropriate because the organization of a forest fire protection service or, as it was then called, a "fire ranging" service, in mid-western Canada coincided to a reasonably close approximation with the period in which Saskatchewan and Alberta came into being. As the Superintendent of Forestry said a few years later with reference to the problems then confronting forestry in Canada, "The first and most important question is the prevention of fire."

After a lapse of nearly fifty years, I believe that this statement is still a valid one. Had the speaker been with us today, he might well have made reference also to the prevention of loss from insects and diseases. I am sure all of us will agree that the protection of the forest from wasteful depletion of any kind is a matter of prime importance to the forestry profession.

\section{Early Days of Forest Fire Protection}

Legislation dealing with forest fires had been on the statute books of the Northwest Territories (which then included Alberta, Saskatchewan and the northern part of Manitoba) for about a quarter of a century prior to the year $1905^{\circ}$. The administration of these laws was, for many years, to all intents and purposes carried out entirely by the Northwest Mounted Police, and again to quote from the Superiniendent of Forestry of that day, "No better men could be employed." However, then as now, the Mounties had many other laws to administer and duties to perform throughout the vast region of the Great Plains.

${ }^{1}$ Opening Address on Forest Fire Protection Annual Meeting, Canadian Institute of Forestry Saskatoon, Sask., October 5, 1955.

2Chict, Forest Operations Division, Forestry Branch, Department of Northern Affairs and National Resources, Ottawa.

${ }^{3}$ Historical references and dates have been obtained from the most reliable sources available to the author. He would appreciate being informed of any inaccuracies in the statements made. 
At the turn of the century it became evident that a fire ranging force, similar to those already existing in several of the Eastern Provinces, would have to be established if the forest reserves that were then being set aside for continuous timber production in the Prairie Provinces were, in fact, to serve the purpose for which they were dedicated. Thus, from the year 1900 on, the first forest protective organizations, as such, in the Prairie Provinces came into being.

Having been given the privilege of introducing the subject of forest fire protection at this meeting, perhaps the remainder of my time could be spent to best advantage by outlining some of the highlights in its development during the past 50 years. This may serve as a useful background for the papers we are to hear later dealing with the present status of forest fire protection, and perhaps some of the trends that may be expected in future.

If I were asked to define in a single word the feature which has most characterized the growth of forest fire protection in Canada during the past half century, it would be by the term "specialization". Now too much specialization can be a bad thing. However, I do not think anyone can accuse any branch of forestry of having reached that unenviable state as yet. Indeed had it not been for the specialization that has taken place in the profession, the forests of Canada would certainly be in a far worse state today than even the most confirmed pessimists would have us believe.

Be that as it may, it would be difficult to find a more completely unspecialized set of duties than those carried out by the fire ranger of 1905 . The classic definition of forest fire protection functions, as you know, includes prevention, detection and suppression, together with a number of miscellaneous items relating to such matters as communications, transport, organization and training, sometimes known collectively as "pre-suppression".

The fire ranger of early days combined all these duties and carried them out, mostly single-handed, throughout his district which, by present standards, was a vast area indeed. He put up fire posters, talked to local settlers and travellers about the need for preventing fires, entreated them to be careful, warned them of the penalties for failing to be careful and, on occasion, arrested those who disregarded his advice. He carried out long fire detection patrols by canoe, on horseback or on foot as circumstances dictated. When he discovered a fire, if it was too large to put out himself (as it probably was), he rounded up whatever men he could find and directed fire-fighting operations. His equipment consisted mainly of shovels, axes and canvas buckets-ancestors of a prolific line of specialized hand fire-fighting tools of today, and still very useful implements in their own right.

\section{Fire Prevention}

Apart from the setting up of the fire ranging services themselves, perhaps the first major example of specialization in forest fire protection in Canada was in the field of fire prevention. In the year 1900 the Canadian Forestry Association was founded. Although the education of the public in forest fire prevention is by no means the only object of this Association, it was from the outset one on which major emphasis was placed. The task of creating a forest-fire conscious public was, and still remains, a formidable one. The governments, the forest industries, and the people of Canada as a whole owe much to the efforts of 
the Canadian Forestry Association and other conservation societies throughout the country, in keeping their fire prevention message in the public eye during the past 55 years.

\section{RAILWAy FIREs}

The history of railway fires in Canada affords an outstanding example of what can be accomplished in forest fire prevention. In 1910 about one-third of all forest fires of known cause were attributed to the railways. During the next three years, regulations were set up under the Railway Act of Canada with a view to correcting this situation. Through the combined efforts of the Board of Railway Commissioners, the railway companies, and the government forest protection services, the proportion of fires caused by railways was progressively reduced until it reached a low of three per cent of the total in the late 1930's. This figure rose considerably during the Second World War because of greatly increased railway traffic and other causes, but during the last ten years it has again declined substantially. This shows what can be done by wise legislation implemented with the co-operation and goodwill of all concerned.

\section{SLash Disposai}

The permit system for settlers' land-clearing fires had been introduced shortly before this resolute attack on the railway fire problem was undertaken. By 1910 the hazard resulting from logging slash had received statutory recognition, and for more than a decade the problem of logging slash disposal was warmly debated. On the question "to burn or not to burn" the majority of government foresters were in favor, while the industry was generally opposed. Disposal of logging slash was tried by a few operators in the East, without enthusiasm, as early as 1912, but in the main these experiments were of short duration. Disposal by burning and by lopping was also tried in the West, and there it fared considerably better.

In any event, the debris left after logging operations still remains the most dangerous fuel in the woods, and the one most feared by fire fighters. It now looks as though improved silvicultural practices and closer utilization of small and defective material may, at long last, be coming to the fire fighters' aid, but the slash problem is still very far from solution.

\section{Detection}

Specialization in forest fire detection may be said to have started with the erection of the first lookout towers about 1912. Twenty lookouts were reported in Canada in 1913. Today the figure is probably well above $1,200$.

The first regular use of aircraft for fire patrols in Canada, and so far as I have been able to discover anywhere in the world, was in 1920. The airplane soon established itself as indispensable, not only for fire detection, but also for transportation of equipment and personnel, and in some cases for fire prevention work. Differences of opinion still exist as to whether, under given circumstances, the lookout system or air patrols are the more efficient. However, it has been generally established that a well-planned lookout network gives the most effective coverage in areas requiring intensive protection, while aircraft provide valuable reinforcement when smoke haze is heavy, and in regions where extensive coverage is afforded. 
We should not lose sight of the fact that public co-operation is still responsible for reporting a high proportion of forest fires. Information from several sources indicates that nearly half of all fires are first reported by the public, and this proportion has not changed radically in a good many years.

\section{COMMUNiCATIONS}

In the field of communications, the telephone was early adapted to meet forestry requirements, and during the first two decades of this century, specialized telephone instruments and methods of line construction were developed. It is perhaps a curious coincidence that the year 1920, in which the celebrated manual "Methods of Communication Adapted to Forest Protection" was published, also saw the first recorded use of radio for forest fire protection in Canada. Forestry telephone systems have undergone little basic change since that time. The manual of 1920 is still highly regarded as a textbook, and the average forest ranger can carry out most telephone installation and repair work.

Not so with the radio, which spread progressively into the woods with low frequency equipment in the 1920's, advanced at a greatly accelerated pace in the high frequency band in the 30's, and during the past ten years has begun to follow the trend to very high and even ultra high frequencies-a move which was pioneered twenty years ago. Most forest services have long since turned over the installation and maintenance of their radio networks to specialists in this field.

\section{TRANSPORTATION}

In the early days roads were very few and far between, even in the so-called "accessible" forested regions of the country. The advent of the airplane was a tremendous boon for transporting men and equipment to fight fires, and the helicopter is now proving itself a worthy partner. Nevertheless, an adequate system of roads and trails remains a basic requirement for the kind of protection needed to support intensive forest management.

Access roads are, of course, also essential to proper management itself. This is another case where protection, silviculture and utilization go hand in hand, but the rate of progress in many areas is too slow to meet present-day protection needs.

\section{Training, Planning, and Organization}

The 1920's saw major advances in the field known today as "pre-suppression". This included the establishment of the first forest ranger schools and the intensified use of fire control plans. Consideration was given as early as 1923 to the setting up of standards of adequate forest fire control, although it was realized that fire protection still had a long way to go before it could be considered as meeting any acceptable objective.

Systematic studies of the relationship between weather and forest inflammability were initiated in Canada in 1916, and the first fire weather forecasts were issued by the Canadian Meteorological Service in 1925. Research in forest fire behavior was intensified in the 1930's, and fire danger ratings are now widely used as a basis for planning the day-to-day duties of fire control personnel. 
Mention should also be made of the Canadian Forest Fire Conference of 19.24, which was attended by federal and provincial ministers, deputy ministers and senior officials responsible for forest administration. A full discussion of fire protection problems took place over a five-day period with highly beneficial results, some of which have already been mentioned. There have been no subsequent conferences at this level for the same purpose. However, the annual meetings of the Associate Committee on Forest Fire Protection of the National Research Council have, for some years past, served as a very useful medium for the discussion of problems of mutual concern, and the exchange of information on fire protection matters from various parts of the country.

\section{FIre SUPPREsSION}

Turning now to fire suppression, it has been my observation that new developments in fire-fighting equipment and techniques have been greeted more enthusiastically and taken up more quickly by fire protection services than the fruits of research in any other branch of fire protection. Perhaps this stems from the same psychology that has prompted those responsible for providing funds for forest fire protection to be, on occasion, very cautious about expending money on fire prevention, or on building up a fire control service capable of taking fast and effective action on fires while they are still small. Yet, when large fires occur, money may be spent lavishly in an effort to put them out.

The development of specialized hand tools for digging, raking, scraping and beating out fires began at an early stage in the history of organized fire protection. Somewhat later came the back-pack tank and hand pump. Refinements in hand fire-fighting tools are still being made, although the basic designs have not changed radically in recent years.

One of the most important contributions to the fire fighters's stock of equipment was the gasoline-powered pump. According to the record the first strictly portable unit of this type was developed in Canada, and was first used on a fire at Banff in 1915. There may be a few here today who have nostalgic memories of these early machines with their shiny copper water-jackets, a hand crank on the flywheel, weighing 130 pounds and capable of pumping 20 gallons a minute. There are pumps on the market today weighing half as much that can deliver three times as much water.

Subsequent developments in forest fire fighting apparatus and methods can merely be touched upon. They include the tank truck, the slip-on tank, the use of stand-by suppression crews, the introduction of smoke-jumpers to Canada (here in Saskatchewan), and the development of water-bombing techniques and the use of helicopters for a variety of fire-fighting activities.

\section{Cost of Fire Protection}

All these developments in fire protection over the years have, of course, been accompanied by progressively increasing cost. In 1923 the estimated fire-protection expenditure on the 860,000 square miles then under protection in Canada was about $\$ 3,000,000$, or an average of roughly one-half cent per acre protected. By 1953 the protected area had grown to $1,250,000$ 
square miles and the total cost of protection for that year was over $\$ 19,000$,000 , or nearly two and one-half cents per acre on the average. As a conservative estimate, and after making allowance for the change in value of the dollar, twice as much in the way of goods and services were applied to forest fire protection in the decade ending in 1953 as in the decade beginning 30 years earlier.

\section{ACCOMPLishMENTS}

To what extent has this increased effort and expenditure been reflected in the reduction of fire losses? Here we must bring statistics to our aid, and unfortunately accurate records of forest fire losses were not kept on a nationwide basis until the late 1920's. However, from the information available it would seem that the number of fires was about 6 percent lower in the period 1944-53 than in 1924-33, while the total area burned was reduced by some 27 per cent.

Both of these trends are in the right direction, but they are disappointingly small. From 1944-53 the merchantable timber alone on burned areas equalled one-quarter of the entire consumption of Canada's pulp and paper industry. This takes no account of the enormous losses of young growth, reduction of site quality, and damage to such increasingly important factors as streamflow, wildlife, recreation and tourist values. Morever, the burning rate of productive forests averaged two-tenths of 1 per cent per year during this period -a figure nearly twice as high as the objective indicated by a study made several years ago of acceptable standards of fire protection in Canada's forests.

In summary, I should like to leave with you three conclusions suggested by this analysis. First, our fire prevention effort over a period of many years has done little more than keep pace with the greatly expanded use of the forest for industry and recreation. Secondly, although we applied at least twice as much in the way of goods and services to fire protection in the decade $1944-53$ as in the decade 1924-33, this was accompanied by a reduction of little more than one-quarter in the area burned. Third, in view of the very modest expenditure on fire protection during most of the last 50 years, the results accomplished have indeed been substantial, and in some respects remarkable. In retrospect, forest fire protection in Canada has come a long way during this period. But, in terms of present need and the future safeguarding of our forest wealth, I think we must all admit that we still have a very long way to go. 